\title{
Camptodactyly: Occurrence in Two New Genetic Syndromes and its Relationship to Other Syndromes
}

\author{
RICHARD M. GOODMAN, MARIASSA BAT-MIRIAM KATZNELSON, and \\ ELI MANOR
}

From the Departments of Human Genetics and Family Medicine, Tel Aviv University Medical School and The Chaim Sheba Medical Center, Tel Hashomer, and the Department of Medicine, Shmuel Harofe Government Hospital, Be'er Ya'acov, Israel

The term camptodactyly was coined by Landouzy (1906) to describe a form of contractures of the fingers. The aetiology of this defect is heterogeneous; it may be either genetic or occur as a sporadic event of unknown cause (Gordon, Davies, and Berman, 1969). It is further known that several independent heritable disorders are associated with camptodactyly (Welch and Temtamy, 1966).

Recently we have studied two separate families each of which presented with camptodactyly. The main constellation of findings in addition to camptodactyly were identical in the affected members of each family, but one family differed markedly from the other. Since we have been unable to find previous reports describing these observations they seem to represent two new genetic syndromes. The purposes of this communication will be to give a detailed clinical account of each syndrome and to discuss the possible significance and relationship of camptodactyly in various genetically determined conditions.

\section{FAMILY A}

\section{Syndrome of Camptodactyly with Muscular Hypoplasia, Skeletal Dysplasia, and Abnormal Palmar Creases}

Clinical Findings. The proposita is a 17 -yearold girl of Jewish Moroccan ancestry who was referred to our clinic for evaluation of multiple congenital anomalies. The patient has been in relatively good health except for having had previous surgery for bilateral clubbed feet. Though she denied a history of any definite muscle weakness, she did state that she was unable to participate in any strenuous activity due to lack of stamina. She is of normal intelligence and is considered to be a

Received 10 November 1971. good student. Her menstrual periods are normal and menarche started at age $14 \frac{1}{2}$ years.

Physical examination showed a 17-year-old girl appearing younger than her stated age with obvious malformations. Her height was $148.6 \mathrm{~cm}$. There was asymmetry of the face with the right side being less prominent than the left (Fig. 1A). The mouth was small with an increased philtrum length and there was a high arched palate. She had a prominent forehead with mild frontal bossing. The head was brachycephalic and measured $54 \mathrm{~cm}$ in circumference. A moderate degree of ocular hypertelorism was present.

\section{TABLE I}

COMMON CLINICAL FEATURES WITH DEGREE OF SEVERITY NOTED IN MEMBERS OF FAMILY A

\begin{tabular}{|c|c|c|}
\hline \multirow{2}{*}{ Location and Defect } & \multicolumn{2}{|c|}{ Degree of Severity } \\
\hline & $\begin{array}{l}\text { III.1 (proposita; } \\
\text { क aged 17) }\end{array}$ & $\begin{array}{c}\text { III. } 3 \text { (affected sib ; } \\
\delta \text { aged 13) }\end{array}$ \\
\hline $\begin{array}{l}\text { Stature } \\
\text { Short } \\
\text { Skull } \\
\text { Brachycephaly } \\
\text { Prominent forehead } \\
\text { Facies } \\
\text { Asymmetry } \\
\text { Ocular hypertelorism } \\
\text { Small mouth } \\
\text { High arched palate } \\
\text { Increased philtrum length } \\
\text { Chest } \\
\text { Thoracic scoliosis } \\
\text { Winging of scapulae } \\
\text { Extremities } \\
\text { Camptodactyly } \\
\text { Syndactyly } \\
\text { Abnormal hand prints } \\
\text { (palmar creases) } \\
\text { Spindle-shaped fingers } \\
\text { Clubbed feet } \\
\text { Muscular system } \\
\text { Hypoplasia of chest } \\
\text { Hypoplasia of pelvis } \\
\text { Hypoplasia of limb and } \\
\text { hand muscles }\end{array}$ & $\begin{array}{l}+ \\
+ \\
+ \\
++ \\
+ \\
+ \\
+ \\
+ \\
+ \\
+ \\
+ \\
+ \\
+ \\
+ \\
+ \\
+ \\
+ \\
+\end{array}$ & $\begin{array}{c}+ \\
++ \\
+ \\
+ \\
+ \\
+ \\
+ \\
+ \\
++ \\
++ \\
++ \\
++ \\
+ \\
+ \\
+ \\
++ \\
++ \\
++\end{array}$ \\
\hline
\end{tabular}

$++=$ More severely affected. 


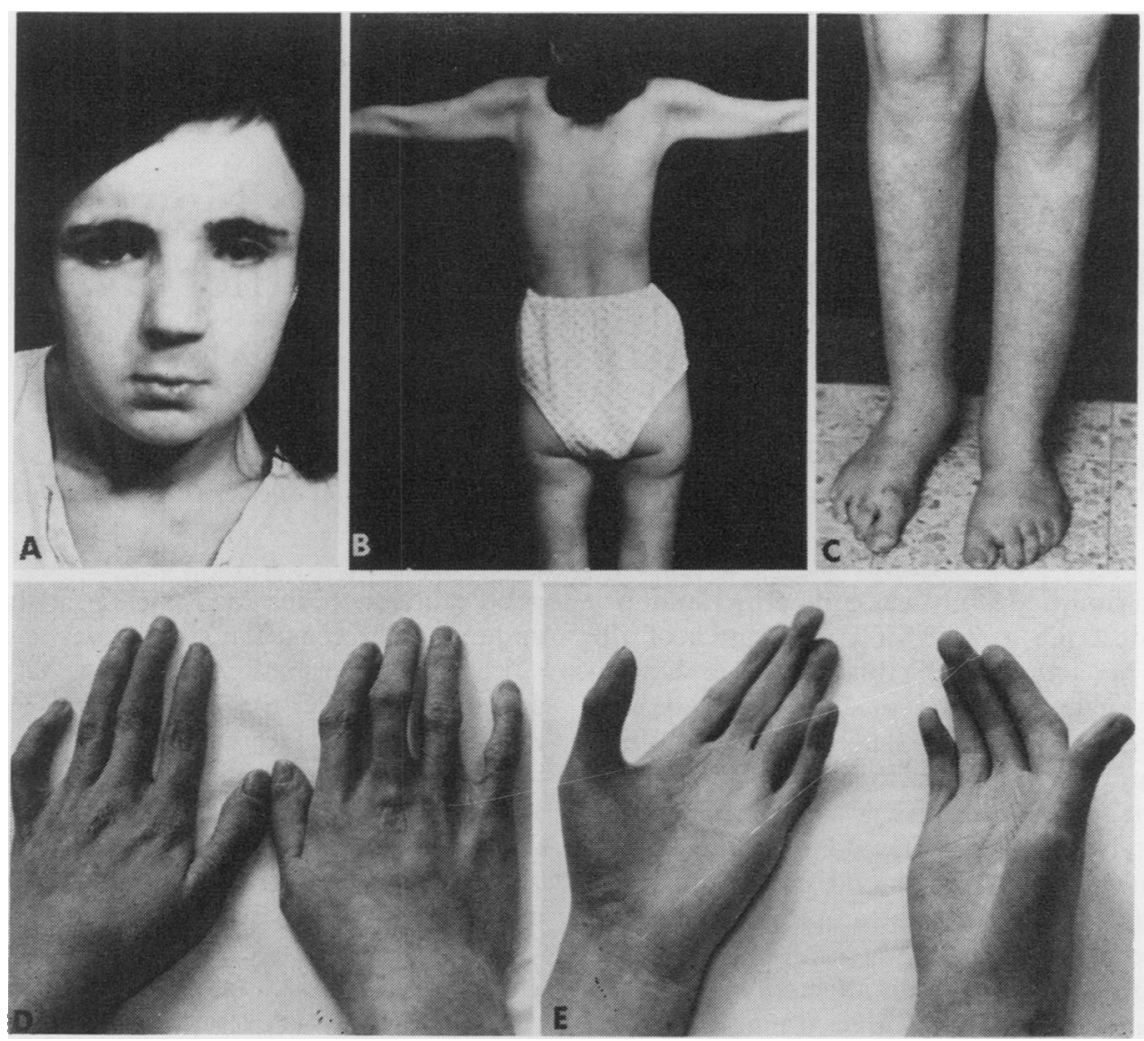

FIG. 1. A: the proposita's face showing asymmetry, mild ocular hypertelorism, small mouth, and an increased philtrum length. $\mathbf{B}$ and $\mathbf{C}$ : poor muscular development involving the upper and lower extremities. $\mathbf{D}$ and $\mathbf{E}$ : spindle-shaped fingers with camptodactyly and hypoplasia of the hand muscles.

In general most of the patient's voluntary muscular system was poorly developed and lacked normal tone. Both the upper extremities and lower portion of the legs appeared abnormal in contour due to poor muscle development (Fig. 1B and C). It was difficult to palpate a definite muscle mass in these areas. There was 'winging' of the scapulae and the flesh about the arms and shoulders hung loosely (Fig. 1B). Both the hip and gluteal regions also showed poor muscle development. There was a moderate degree of scoliosis to the left involving the thoracic spine.

The hands showed bilateral camptodactyly with greater deformity of the right hand. On the right hand fingers $2,3,4$, and 5 were flexed, while on the left only the 5 th digit was affected. The thenar and hypothenar eminences were poorly developed as well as all the hand muscles. All fingers were spindle in shape and the right thumb nail was shorter than the left (Fig. 1D and E). An abnormal dermatoglyphic pattern was grossly visible on the surfaces of the palms and feet. Despite her previous surgery she continued to have a mild clubbed foot deformity.

The remainder of the physical examination including that of heart, lungs, abdomen, and nervous system were all within normal limits.

One of the proposita's sibs, a brother aged 13, was found not only to physically resemble the proband but in some features he was more severely affected (Fig. $2 \mathrm{~A}-\mathrm{F}$ ). He also appeared younger than his stated age and showed obvious malformations. His height was $142.2 \mathrm{~cm}$ and he had a head circumference of $56 \mathrm{~cm}$. Like his sister he gave no history of muscle weakness but could not participate in sports due to lack of endurance. In his early childhood he had also been operated on for bilaterally clubbed feet. Table I (p. 203) lists and compares the main clinical findings as observed in these two affected sibs. In addition to these identical features listed, the brother also displayed blue sclerae, webbing of the fingers, a grade 2 systolic murmur, and a left inguinal hernia. 


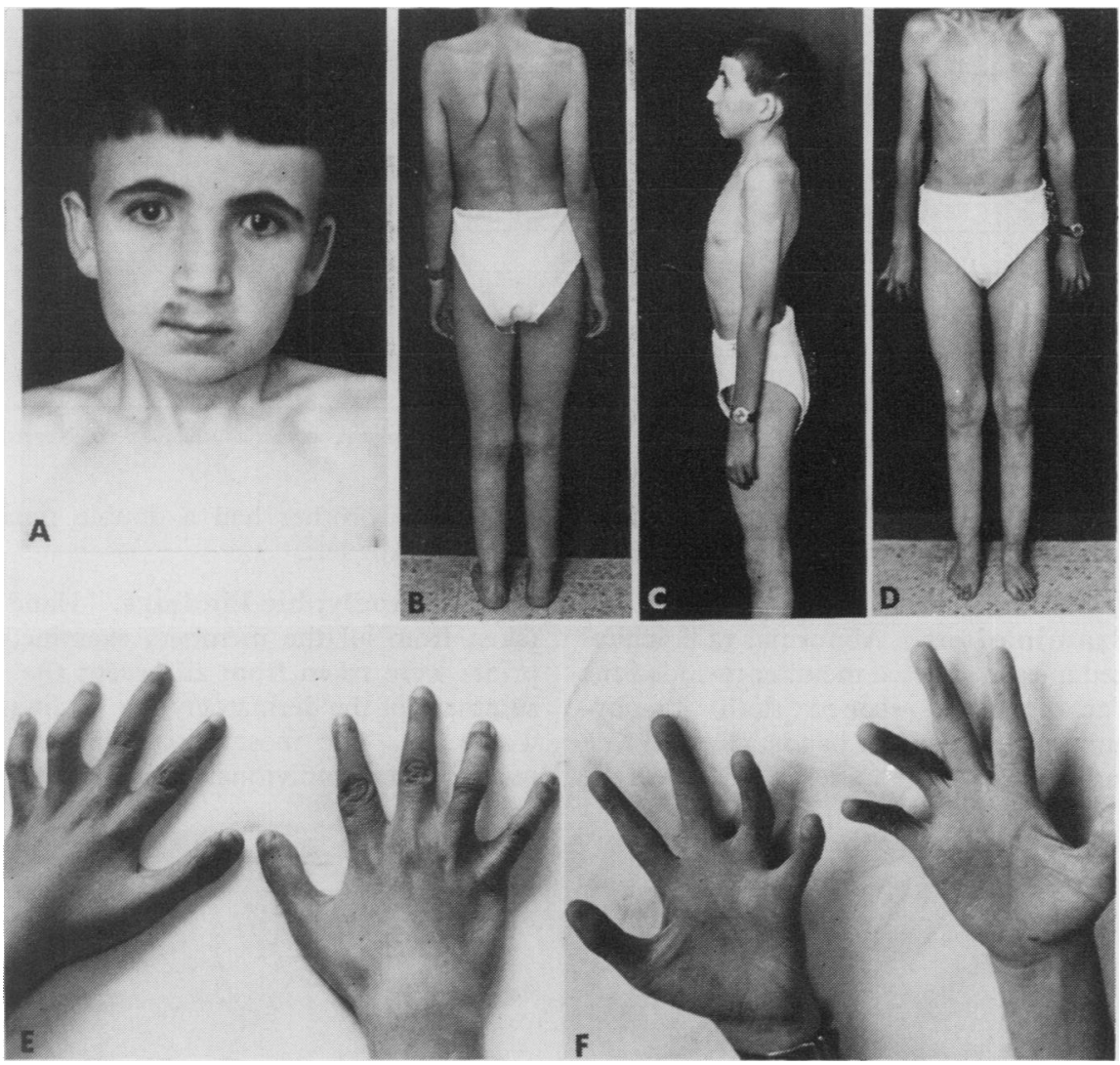

FIG. 2. A: the face of the proposita's sib with slight facial asymmetry, mild ocular hypertelorism, small mouth and increased philtrum length. B, C, and D: poor muscular development as noted by 'winging' of the scapulae, scoliosis, lumbar lordosis, and the unusual straight contour to the shape of the lower legs. E and F: spindle-shaped fingers with camptodactyly, syndactyly, and poorly developed hand muscles. Note the marked similarity between the features of this patient and his sister, the proposita (see Fig. 1).

I

II

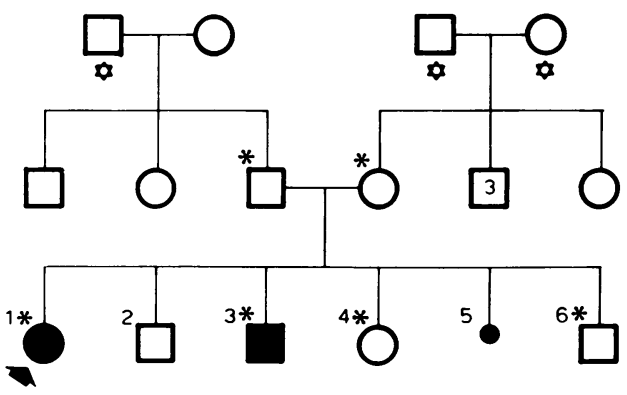

Figure 3 shows the family pedigree. No other members of the family were known to be affected and there was no history of consanguinity. However, it is of interest that both parents are from small neighbouring communities in Morocco.

Laboratory Investigations. Unfortunately, various conditions made it impossible to carry out all the laboratory studies that should have been done. Nevertheless, the following examinations were performed on both affected members and were within normal limits: serum and urine amino acids, serum aldolase, creatin phosphokinase, transaminase (SGOT and SGPT), creatinine, creatine, and a chromosomal analysis from peripheral leucocytes.

Two years previously, the proposita's brother was hospitalized and a variety of tests, including various serum protein studies, electroencephalogram, electrocardiogram, serum phosphorus, calcium, and 
TABLE II

DERMATOGLYPHIC FINDINGS IN FAMILY A

\begin{tabular}{l|c|c|c|c|c|c|c}
\hline \multicolumn{1}{|c|}{ Family Members } & $\begin{array}{c}\text { Number of } \\
\text { Whorls }\end{array}$ & $\begin{array}{c}\text { Total Ridge } \\
\text { Count }\end{array}$ & $\begin{array}{c}a-b \\
\text { Ridge Count }\end{array}$ & $\begin{array}{c}\text { Ridge Breadth } \\
\text { (microns) }\end{array}$ & $\begin{array}{c}\text { Maximal atd } \\
\text { Angle }\end{array}$ & $\begin{array}{c}\text { Main Line } \\
\text { Index }\end{array}$ & $\begin{array}{c}\text { Modification } \\
\text { of Creases }\end{array}$ \\
\hline III.1 (proposita) & 8 & $271^{*}$ & 73 & 606 & $110 \cdot 5^{\circ}$ & $?$ \\
\hline III.3 (affected sib) & 8 & $350^{*}$ & 120 & 536 & $101 \cdot 0^{\circ}$ & $?$ & + \\
\hline III.4 & 3 & 135 & 75 & 428 & $76 \cdot 0^{\circ}$ & $7 \cdot 1$ \\
\hline III.6 & 4 & 179 & 90 & 385 & $90 \cdot 5^{\circ}$ & $5 \cdot 7$ & - \\
\hline Father & 3 & 163 & 79 & 561 & $71 \cdot 0^{\circ}$ & $6 \cdot 7$ \\
\hline Mother & 1 & 181 & 82 & 533 & $82 \cdot 0^{\circ}$ & 6.9 & - \\
\hline
\end{tabular}

* In not all fingers could the triradii be located so that in a few instances the ridge count is only an approximation. Nevertheless, the total ridge count is exceptionally high.

electrolytes were all within normal limits. No muscle biopsy or electromyographic studies have ever been done.

X-ray Examinations. Abnormal radiological findings noted in each affected member included the following: an abnormal shaped skull (brachycephaly), camptodactyly of the hands, clubbed foot deformity and scoliosis of the spine. In addition the proposita's brother had a double renal collecting system on the left.

Dermatoglyphic Findings. Hand prints were taken from all the members examined while foot prints were taken from all except the parents. A summary of the dermatoglyphic findings is noted in Table II. The most outstanding feature of the two affected individuals was that their normal

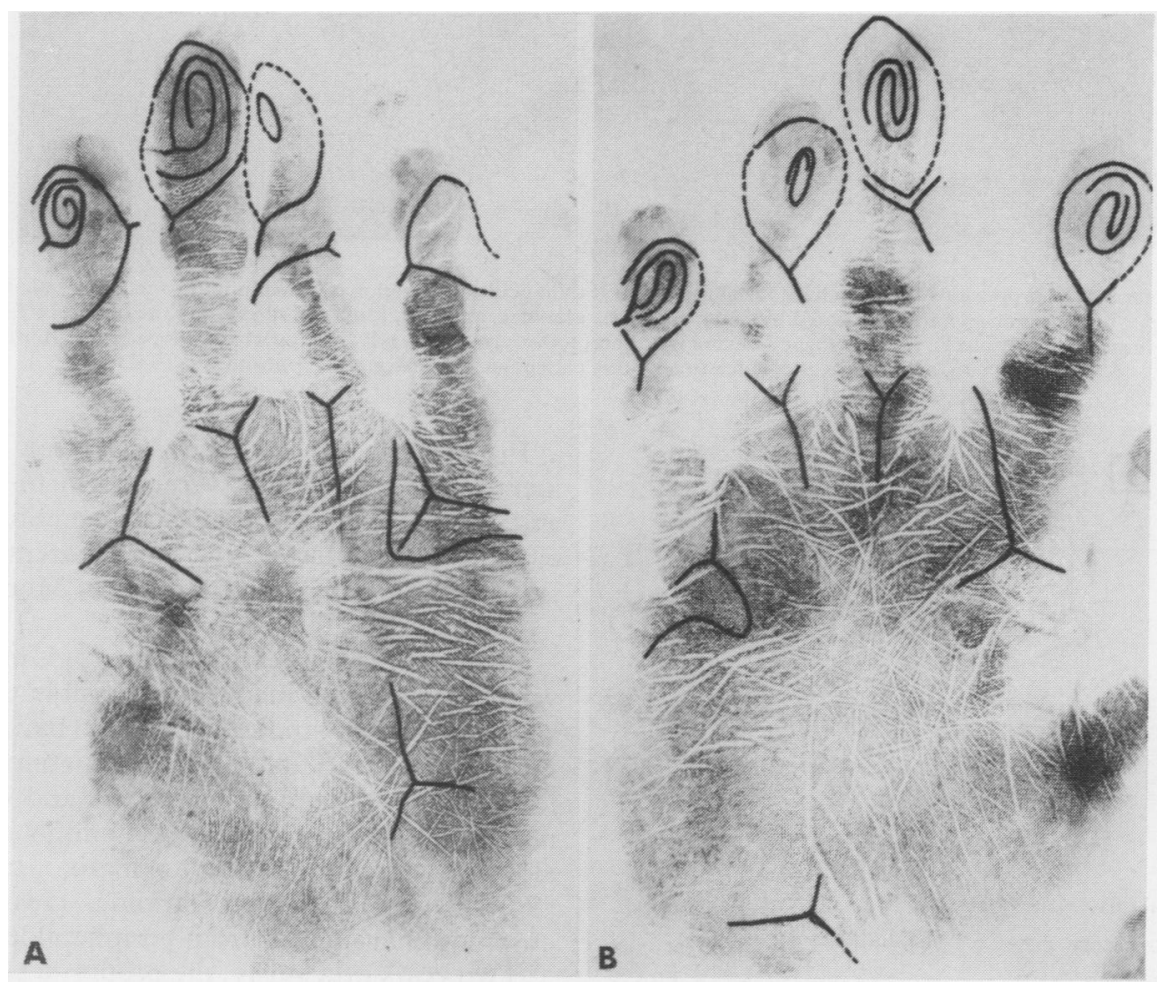

FIG. 4. Dermatoglyphic features in the proposita in family A (A: right hand) and her affected sib (B: left hand). The following changes can be observed in both handprints: absence of interphalangeal creases, large digital patterns (whorls and loops) with displacement of their triradii, the main lines orientated vertically, unusual extension of the $a$ triradii, unusual configuration of $D$ radiant, and wide palmar creases in the upper portion of the palms. 
finger creases were completely absent (Fig. 4A and B). Consequently the ridges covering the surface of the digits appeared in an unusual pattern. In addition they had an increased number of whorls. These whorls differed from normal whorls in that they extended beyond the borders of the terminal phalanges and thus the triradii belonging to the whorls were observed on the middle or even the proximal portions of the digits (Fig. 4A and B). The unusual size of these whorls further resulted in a high total ridge count.

The $a-b$ ridge count was very high in the affected brother. This was due to marked radial displacement of the $a$ triradii on both hands. The affected sister did not show this alteration and thus her $a-b$ ridge count was within normal limits.

The values of the maximal atd angle were greater than normal in the 2 affected sibs. Due to the severe distortion of the ridges, the main line index could not be determined in the 2 affected individuals. In addition, the orientation of the palmar ridges was vertical in contrast to the usual diagonal arrangement. A mild degree of syndactyly was noted in the left palm of the proband and this trait was definitely observed in both palms of her affected brother.

Another interesting observation noted in the 2 affected sibs was the unusual exit of the $D$ radiant. It was either aborted at its exit point or it left the $d$ triradius on the ulnar side of the palm. Sometimes it formed an ulnar loop on this side of the palm. This finding was not observed in the other family members and to the best of our knowledge it does not appear in the normal population.
As commented upon earlier, there was a complete absence of phalangeal creases, not only involving the distal segments as found in cases of trisomy 18 (Penrose, 1969) but on all portions of the digits. The palms of these 2 individuals also showed a large number of coarse creases running horizontally (Fig. 4A and B). The creases were more numerous on the distal portions of the palms and the distance between them was relatively small.

Microscopically the ridges in most areas of the palms were fused and lacked the normal clarity and spacing. Normally appearing ridges were found in only a few scattered areas of the hypothenar regions. The sweat pores were not well defined.

An increased number of whorls was also noted on the toes of the two affected sibs while their other sibs had no whorls at all. Their soles were identical to the palms in that there was a complete absence of digital creases and many horizontal, coarse creases were observed in the distal portions of the soles.

\section{FAMILY B}

\section{Syndrome of Camptodactyly with Fibrous Tissue Hyperplasia and Skeletal Dysplasia}

Clinical Findings. The propositus is a 19year-old man of Jewish Iranian ancestry who was referred to our clinic for evaluation of possible Marfan's syndrome. At 7 years of age he was operated for ligation of a patent ductus arteriosus. The patient completed schooling to the 10th grade and appeared to have a lower than normal intelligence. Though his body proportions were suggestive of Marfan's syndrome there was little else in

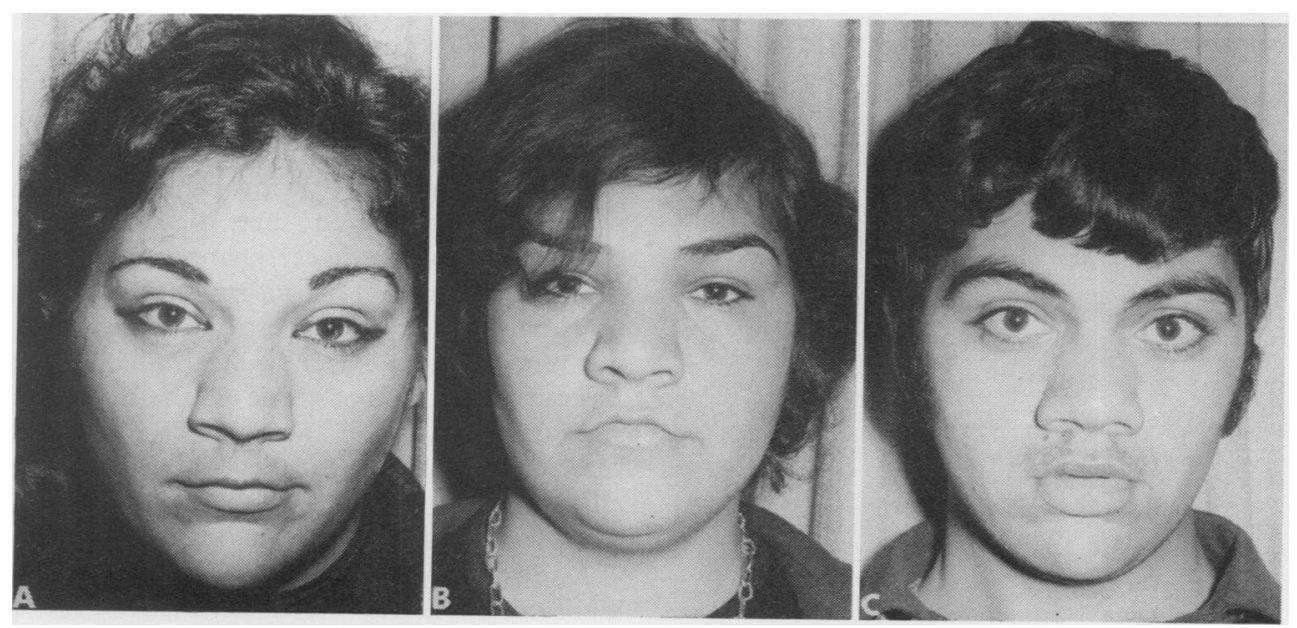

Fig. 5. A, B, and C: the facial appearance of the 3 affected sibs of family B. The propositus is shown in C. Note the broad nose and flaring of the nostrils. These nasal features are in contrast to most Iranian Jews who have a thin nose with narrow nostrils. 
the way of family history or physical findings to make this diagnosis.

Physical examination showed a young man appearing in good health with an obvious deformity of the
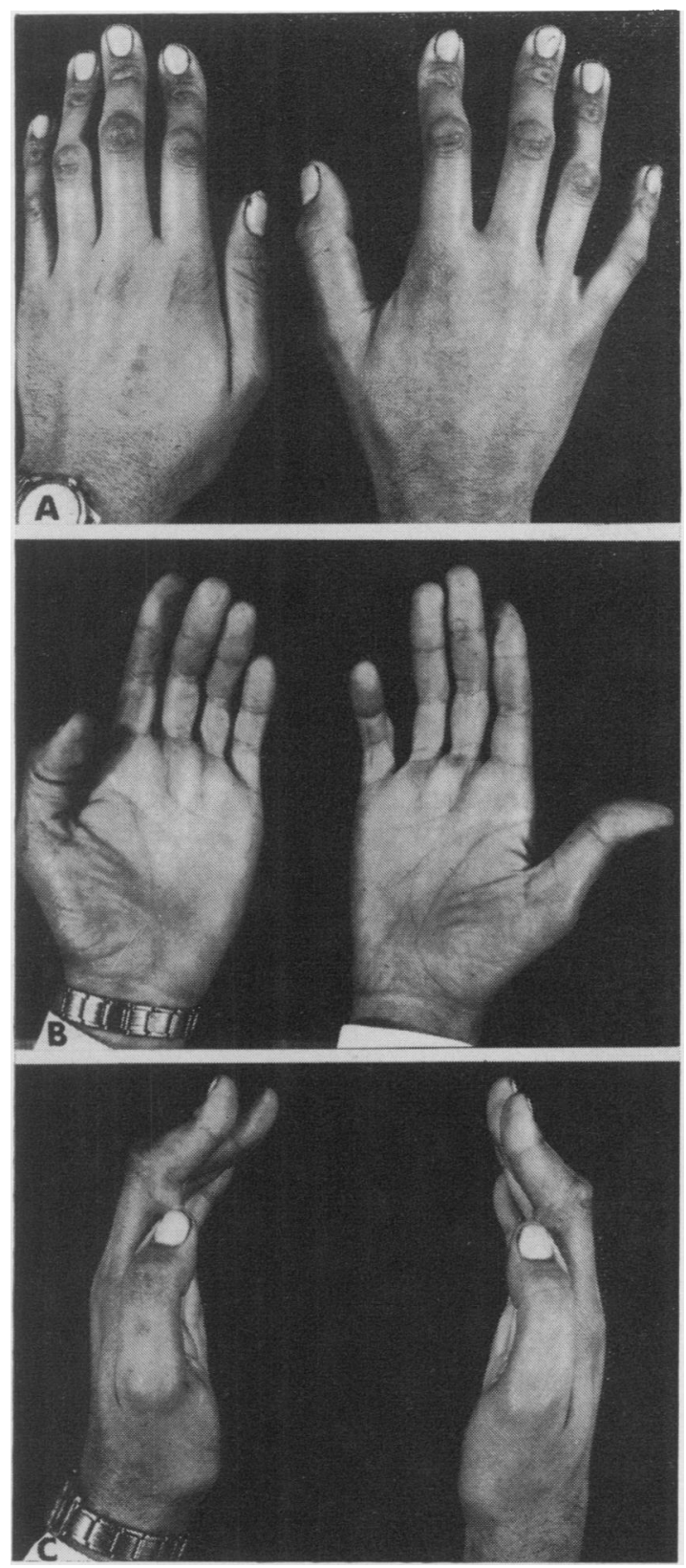

FIG. 6. A: the propositus' hands with knuckle pad formation on the 2nd, 3rd, and 4th fingers. $B$ and $C$ : the extent of the flexion deformity. The thumbs were held in flexed position by the patient (see $\mathbf{B}$ and $\mathbf{C}$ ) but were not involved.

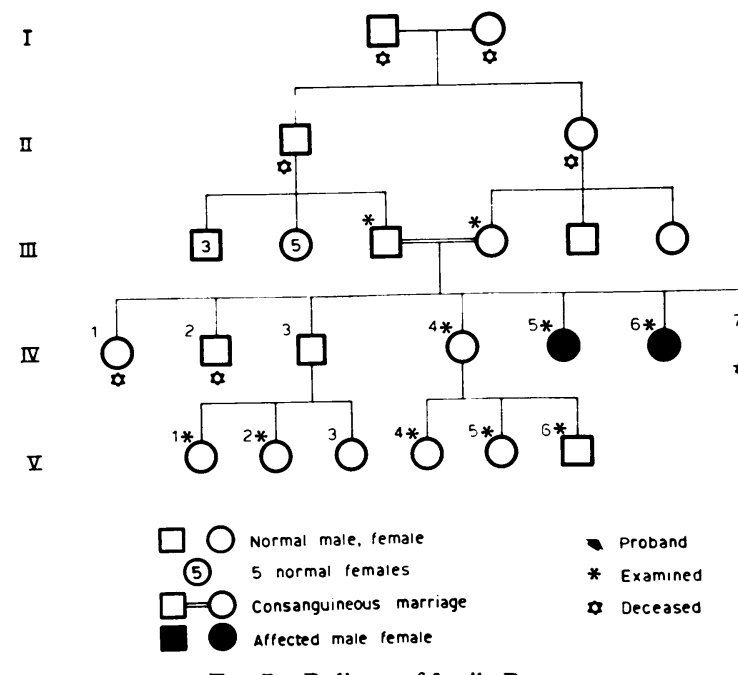

FIG. 7. Pedigree of family B.

hands. His vital signs were within normal limits. He had a height of $175 \mathrm{~cm}$, an arm span of $183 \mathrm{~cm}$, and an upper segment/lower segment ratio of $81 \mathrm{~cm} / 94 \mathrm{~cm}$ or 0.86 . His face showed a broad nose with flaring of the nostrils (Fig. 5C). His hands and feet were exceptionally large for his stature. All digits of the hand except the thumbs showed the changes of camptodactyly, the onset of which was stated to have begun around the age of 10 years. Knuckle pads were observed on the 2nd, 3rd, and 4th fingers bilaterally (Fig. 6). Hammer toes were also present bilaterally. There was a mild scoliosis of the thoracic spine.

He stated that 2 sisters also had the same abnormalities of the hands. All available members of the family were subsequently evaluated and the family pedigree is shown in Fig. 7. The proband's parents are first cousins and were born in Iran. With the exception of the patent ductus both affected sisters were identical in their clinical features to those of the proband. All 3 affected members even stated that they first noted the changes of camptodactyly appearing around the age of 10 years. This information was confirmed by their mother. Furthermore, the facial features of these individuals were quite similar (Fig. 5A and B) and distinct from those of their parents, other sibs and relatives. Table III lists and compares the main clinical features observed in these 3 affected sibs.

Laboratory Investigations. The following laboratory studies were performed on these 3 affected individuals and the results were all within normal limits: urinary amino acids, fasting blood 
TABLE III

COMMON CLINICAL FEATURES WITH DEGREE OF SEVERITY NOTED IN MEMBERS OF FAMILY B

\begin{tabular}{|c|c|c|c|}
\hline \multirow[b]{2}{*}{ Location and Defect } & \multicolumn{3}{|c|}{ Degree of Severity } \\
\hline & $\begin{array}{c}\text { IV-5 } \\
(q \text { aged 24) }\end{array}$ & $\begin{array}{c}\text { IV-6 } \\
(\% \text { aged 21) }\end{array}$ & $\begin{array}{c}\text { IV-7 } \\
\text { (propositus; } \\
\delta \text { aged 19) }\end{array}$ \\
\hline $\begin{array}{l}\text { Facies } \\
\text { Broad nose } \\
\text { Flaring nostrils } \\
\text { Dull expression with } \\
\text { low normal } \\
\text { intelligence } \\
\text { Spine } \\
\text { Thoracic scoliosis } \\
\text { Extremities } \\
\text { Large hands and feet } \\
\text { with archnodactyly } \\
\text { Camptodactyly } \\
\text { Knuckle pads } \\
\text { Hammer toes }\end{array}$ & $\begin{array}{l}+ \\
+ \\
+ \\
+\end{array}$ & $\begin{array}{c}++^{*} \\
+\end{array}$ & $\begin{array}{c}+ \\
+ \\
+ \\
+\end{array}$ \\
\hline
\end{tabular}

$*++=$ More severely affected.

sugar, serum cholesterol, uric acid, calcium, phosphorus, alkaline phosphatase, protein electrophoresis, blood urea nitrogen, PBI, and growth hormone assay.

X-ray Examinations. Various radiological studies of the skeletal system were done and 3 distinct abnormalities were observed in all 3 affected members. These consisted of (1) scoliosis of the thoracic spine, (2) camptodactyly and archnodactyly of the hands, and (3) a hammer toe deformity of the feet.

Dermatoglyphic Findings. Hand and foot prints were taken from all members examined in generations III and IV. No specific finding was observed in the three affected members nor in the other individuals examined. However, one point of interest was the wide ridge breadth (612 to 650 microns) noted in all family members except the mother. This may be an ethnic trait and should be evaluated further.

\section{Discussion}

The distinguishing features in each of these two syndromes are presented in Tables I-III above.

In family $A$ since both sexes are affected and neither parent showed any of the abnormalities noted in their 2 affected children, it is postulated that this syndrome is transmitted as an autosomal recessive and the parents are heterozygous carriers. Though the parents deny close consanguinity, the fact that both came from neighbouring communities suggests the possibility of common ancestry. Neither parent knew of other members of their families with similar defects as observed in their 2 affected offspring. However, one cannot totally exclude dominant transmission with low penetrance.
In family $B$ the parents are first cousins and neither showed any of the pathological findings observed in their affected offspring nor did they know of other members with similar findings. The fact that there is close consanguinity, the parents are not clinically affected, and those affected are both male and female in the same sibship makes an autosomal recessive mode of transmission most probable.

An interesting clinical point is that camptodactyly occurring alone or in association with other abnormalities to form a syndrome, has been previously known to be transmitted only as a dominant (Welch and Temtamy, 1966). This mode of inheritance is also true for the many other genetically determined malformations of the hands. The question arises as to why should we be seeing this defect in 2 syndromes whose inheritance seems to be recessive. The answer to this question is not clear but we do know that a similar situation exists in the Ellis-vanCreveld syndrome. In this syndrome, which is inherited as an autosomal recessive, polydactyly, which is an integral part of the syndrome, is by itself always transmitted as a dominant (McKusick et al, 1964). Furthermore, there are a few genetic disorders which can be transmitted as either a dominant or a recessive. These include such conditions as Charcot-Marie-Tooth disease, retinitis pigmentosa, spastic paraplegia, osteogenesis imperfecta, and achondroplasia (McKusick, 1968). Variations in modes of transmission among certain traits and diseases raise many interesting questions with regard to the mechanisms of genetic control.

Turning to camptodactyly itself, several terms (see Table IV) have been used to describe this hand

TABLE IV

VARIOUS TERMS USED IN THE LITERATURE TO DESCRIBE A PERMANENT FLEXION CONTRACTURE OF THE FINGERS AT THE PROXIMAL INTERPHALANGEAL JOINTS

\begin{tabular}{|c|c|}
\hline Term & Reference \\
\hline $\begin{array}{l}\text { Congenital contracture of the fingers } \\
\text { Congenital Dupuytren's contracture } \\
\text { Camptodactyly } \\
\text { Streblomicrodactyly } \\
\text { Familial finger contracture } \\
\text { Hammer fingers } \\
\text { Flexed fingers } \\
\text { Palmar clinodactyly }\end{array}$ & $\begin{array}{l}\text { Tamplin (1846) } \\
\text { Keen (1882) } \\
\text { Landouzy (1906) } \\
\text { Von Schmidt (1921) } \\
\text { Murphy }(1926) \\
\text { Whitman (1930) } \\
\text { Spear (1946) } \\
\text { Currarino and Waldman } \\
\text { (1964) }\end{array}$ \\
\hline
\end{tabular}

defect which involves a permanent flexion contracture of the fingers at the proximal interphalangeal joints. In contrast to Dupuytren's contracture, Welch and Temtamy (1966) point out that camptodactyly lacks involvement of the metacarpophalangeal joint, has slower progression with an 
earlier age of occurrence, and there is absence of puckering of the skin with overt palmar involvement. Furthermore, camptodactyly should not be confused with campylodactyly (Hecht and Beals, 1969), which refers to curvature of all fingers at the interphalangeal joints only when the wrist is dorsiflexed. For sake of uniformity and clarity we would agree with Welch and Temtamy (1966) that the original term camptodactyly be used in all cases fitting the description, no matter which digit is involved. In almost all cases this abnormality is bilateral and affects the 5th digit. It may also involve the 4th, 3rd, and 2 nd digits but rarely the 1st digit. There is no limitation to further flexion of the fingers but full extension is not possible. This defect may be present at birth as in family A or more commonly it arises in childhood as in family B. Progression is usually minimal and occurs mainly during the first 2 decades of life.

Following the observations of Parish, Horn, and Thompson (1963) and of Nevin, Hurwitz and Neill (1966) that in some cases of camptodactyly there may be an associated aminoaciduria and particularly taurinuria, urine from all affected members in both families was screened for aminoaciduria. Though we did not study 24-hour urine excretion, no abnormalities in the urinary amino acids were noted. Since some members in these previously reported families had camptodactyly without taurinuria and taurinuria without camptodactyly, it is difficult at this time to properly assess the relationship between these 2 findings. It would seem advisable that all familial cases of camptodactyly should be screened for taurinuria in hopes of better evaluating this observation.

In terms of understanding the basic defect in each of the syndromes described in this report, the few biochemical studies that were performed shed little light in this direction. However, in family $A$ the presence of poor muscle development with normal serum muscle enzyme values suggests a muscular hypoplasia rather than a dystrophy. It is of interest that in Maurer's report (1938), of 31 cases with camptodactyly, 22 individuals had 'winging' or elevation of the scapula. This observation coincides well with what was observed in our family $A$ in which both affected persons have 'winging' of the scapula. Again, this finding most probably reflects poor muscular development due to a hypoplasia of muscle tissue. In family B the only suggestion of a muscle disorder is the presence of scoliosis in all 3 affected individuals and this may be skeletal rather than muscular in nature.

In 1969, Gordon and his coworkers compiled a table listing the various genetic disorders in which camptodactyly may be associated. In considering these conditions it becomes apparent that they all display a significant defect in tissues of mesodermal origin, mainly collagen fibres, muscle, and bone. However, at present the precise alteration is not known for any of these disorders.

With regard to camptodactyly, it is not difficult to conceive that it alone represents some localized defect in connective tissue synthesis and when part of a syndrome it may reflect a more diffuse disturbance in tissues of mesodermal origin. Camptodactyly as a localized alteration in connective tissue can be noted by the longitudinal bands of thickened palmar fascia that may be seen or felt extending from the base of the middle phalanges into the palms.

In patients with camptodactyly one may also observe knuckle pads and flexion contracture of the proximal interphalangeal joints of the toes (hammer toes) (Welch and Temtamy, 1966). In order to produce these pathological changes there must be some alteration in the production of fibrous tissue. We would tend to incriminate the fibroblast cell and state that when this cell is so programmed, its response is that of a localized hyperplasia of fibrous tissue. When this involves the terminal joints the resulting defect is either camptodactyly or hammer toes or both, and when on the dorsal surface of the fingers it produces knuckle pads.

We know that early in embryogenesis cells are multipotential. If a given mesodermal cell contains a mutant gene for a particular disorder of connective tissue, it is conceivable that various tissue of mesodermal origin may exhibit the effects of this altered gene. Thus, such cells as fibroblasts, muscle fibres, and bone cells all of mesodermal origin account for the main sites of tissue involvement with regard to syndromes concerning camptodactyly.

Based on the main clinical findings associated with the various syndromes in which camptodactyly is a part, we would propose that the mutant genes determining these syndromes may produce 3 forms of cellular response: (1) hyperplasia of fibrous tissue, (2) hypoplasia of striated muscle, and (3) dysplasia of bone and cartilage. Fig. 8 depicts the possible pathways involved while Table $\mathrm{V}$ lists the various syndromes associated with camptodactyly including the 2 described in this paper.

In order to investigate this hypothesis further, it would seem worthwhile to culture fibroblasts and muscle cells from affected sites in these syndromes and compare various aspects and components of cell metabolism with cells from identical sites in matched controls. 
Level of Organizational Defect

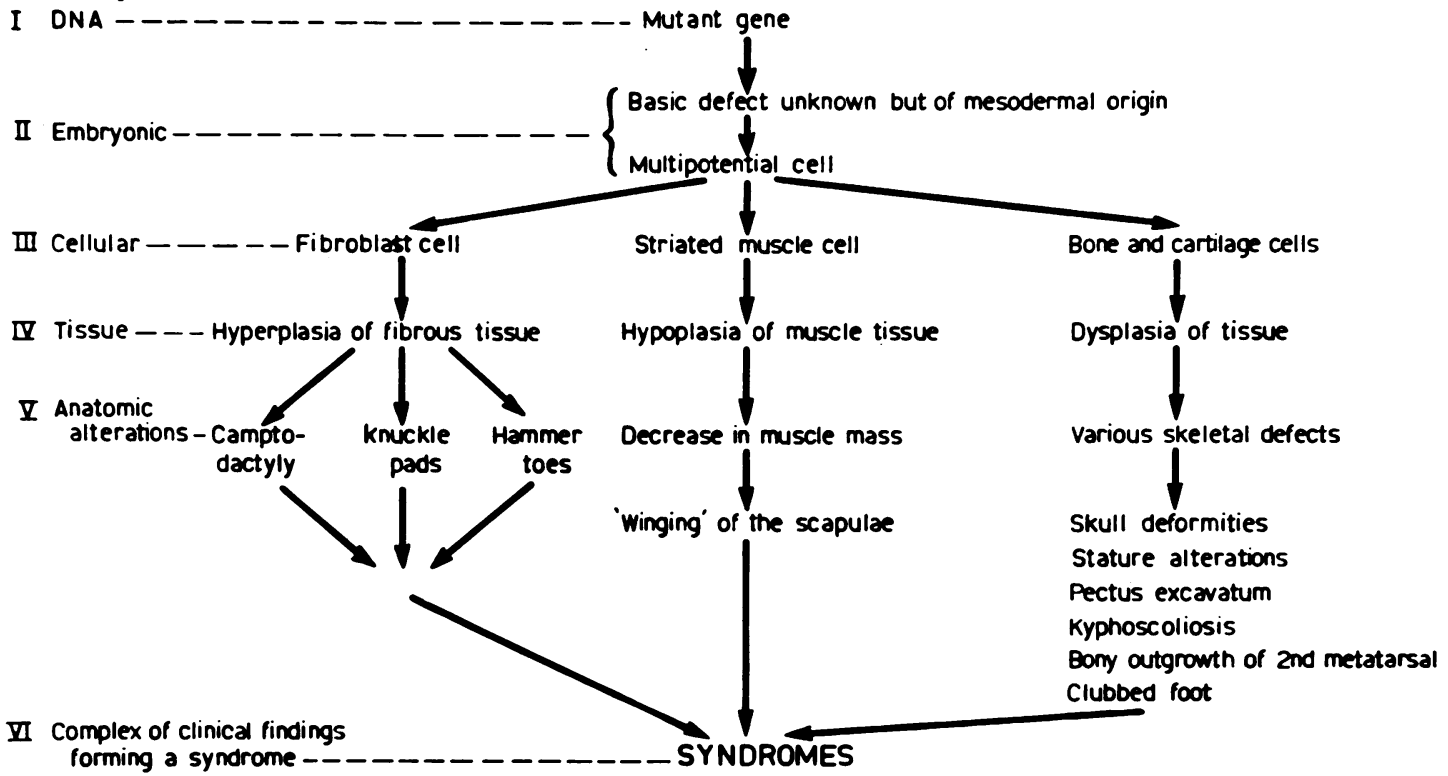

(All of which may have camptodactyly plus various combinations of the above clinical alterations)

Fig. 8. The possible pathways involved in the formation of syndromes associated with camptodactyly and other connective tissue defects.

TABLE V

GENETIC SYNDROMES IN WHICH CAMPTODACTYLY MAY BE OBSERVED

\begin{tabular}{|c|c|c|}
\hline Syndrome and/or Authors & Additional Features & Transmission \\
\hline $\begin{array}{l}\text { 1. Oral-facial-digital (OFD I) (Gorlin, } \\
\text { Anderson, and Scott, 1961) }\end{array}$ & Distinct facies with multiple anomalies of the face and digits & X-linked dominant \\
\hline $\begin{array}{l}\text { 2. Focal dermal hypoplasia, Goltz's } \\
\text { syndrome (Goltz et al, 1970) }\end{array}$ & $\begin{array}{l}\text { Papillomas of the lips, anomalies of the eyes, nose, ears, and } \\
\text { digits }\end{array}$ & $\mathrm{X}$-linked dominant? \\
\hline $\begin{array}{l}\text { 3. Nielson's syndrome (Moldenhauer, } \\
\text { 1964) }\end{array}$ & Pterygium colli, ptosis, and vertebral anomalies & $\begin{array}{l}\mathrm{X} \text {-linked or autosomal } \\
\text { dominant }\end{array}$ \\
\hline $\begin{array}{l}\text { 4. Oculo-dento-digital dysplasia (Gorlin, } \\
\text { Meskin, and St Geme, 1963) }\end{array}$ & Distinct facies with anomalies of the eyes, teeth, and digits & Autosomal dominant \\
\hline $\begin{array}{l}\text { 5. Cranio-carpo-tarsal dysplasia, Freeman- } \\
\text { Sheldon syndrome (Freeman and } \\
\text { Sheldon, 1938) }\end{array}$ & Distinct facies with eye and musculo-skeletal anomalies & Autosomal dominant \\
\hline 6. Marfan syndrome (McKusick, 1966) & Skeletal, ocular, and aortic alterations & Autosomal dominant \\
\hline 7. Maurer (1938) & $\begin{array}{l}\text { Ptosis and skeletal anomalies including pectus excavatum } \\
\text { and kyphoscoliosis }\end{array}$ & Autosomal dominant \\
\hline 8. Baird (1964) & $\begin{array}{l}\text { Complete absence of dermal ridges, syndactyly of the toes, } \\
\text { and transient congenital milia }\end{array}$ & Autosomal dominant \\
\hline 9. Parish et al (1963) & Presence of taurinuria in some cases & Autosomal dominant \\
\hline 10. Gordon et al (1969) & Cleft palate and club foot & Autosomal dominant \\
\hline 11. Present report (Family A) & $\begin{array}{l}\text { Muscular hypoplasia, peculiar facies, skeletal anomalies, and } \\
\text { markedly abnormal dermatoglyphics }\end{array}$ & Autosomal recessive? \\
\hline 12. Present report (Family B) & Broad nose, large hands and feet, and scoliosis & Autosomal recessive \\
\hline
\end{tabular}




\section{Summary}

Two new genetic syndromes presenting with camptodactyly are described. One such disorder has been termed the syndrome of camptodactyly with muscular hypoplasia, skeletal dysplasia, and abnormal palmar creases while the other is referred to as the syndrome of camptodactyly with fibrous tissue hyperplasia and skeletal dysplasia. Both are thought to be transmitted as autosomal recessives. Their clinical features are discussed in detail as well as the possible significance of camptodactyly and its relationship to various genetic syndromes involving certain tissues of mesodermal origin.

We would like to express our appreciation to Professor H. Neufeld and Drs Y. Yahini and A. Maimon for referring the families to us for study; to Professor and Mrs A. Szeinberg, Dr Y. Zak, and Mrs G. Tauman for performing various biochemical studies; to Dr M. Hertz for her radiological assistance; to Mrs E. Molho for her photographic work; to Mrs R. Grossman and Mrs A. Goodman for their secretarial help, and Dr A. Adam for his critical comments.

This study was supported in part by a grant from the Lester Aronberg Foundation.

\section{REFERENCES}

Baird, H. W. (1964). Kindred showing congenital absence of the dermal ridges (fingerprints) and associated anomalies. Fournal of Pediatrics, 64, 621-631.

Currarino, G. and Waldman, I. (1964). Camptodactyly. American Fournal of Roentgenology, 92, 1312-1321.

Freeman, E. A. and Sheldon, J. A. (1938). Cranio-carpo-tarsal dystrophy. An undescribed congenital malformation. Archives of Disease in Childhood, 13, 277-283.

Goltz, R. W., Henderson, R. R., Hitch, J. M., and Ott, J. E. (1970). Focal dermal hypoplasia syndrome. A review of the literature and report of two cases. Archives of Dermatology, 101, 1-11.

Gordon, H., Davies, D., and Berman, M. (1969). Camptodactyly, cleft palate, and club foot. A syndrome showing the autosomal- dominant pattern of inheritance. Fournal of Medical Genetics, 6, 266-274.

Gorlin, R. J., Anderson, V. E., and Scott, C. R. (1961). Hypertrophied frenuli, oligophrenia, familial trembling and anomalies of the hand; Report of four cases in one family and a forme fruste in another. New England fournal of Medicine, 264, 486-489.

Gorlin, R. J., Meskin, L. H., and St Geme, J. W. (1963). Oculodentodigital dysplasia. Fournal of Pediatrics, 63, 69-75.

Hecht, F. and Beals, R. F. (1969). Inability to open the mouth fully: An autosomal dominant phenotype with facultative campylodactyly and short stature. Birth Defects: Original Articles Series, V, 3, 96. The National Foundation-March of Dimes, New York.

Keen, W. W. (1882). The etiology and pathology of Dupuytren's contracture of the fingers. Philadelphia Medical Times, 12, 370378.

Landouzy, L. (1906). Camptodactylie: stigmate organique precoce du neuroarthritisme. Presse Médicale, 14, 251.

McKusick, V. A. (1966). Heritable Disorders of Connective Tissue, 3rd ed. C. V. Mosby, St Louis.

McKusick, V. A. (1968). Mendelian Inheritance in Man, 2nd ed. Johns Hopkins, Baltimore.

McKusick, V. A., Egeland, J. A., Eldridge, R., and Krusen, D. E. (1964). Dwarfism in the Amish: I The Ellis-van Creveld syndrome. Bulletin of the fohns Hopkins Hospital, 115, 306-336.

Maurer, G. (1938). Die Kamptodaktylie. Archiv für Orthopädische und Unfall-Chirurgie, 39, 365-374.

Moldenhauer, E. (1964). Zur Klinik des Nielson-Syndroms. Dermatologische Wochenschrift, 150, 594-601.

Murphy, D. P. (1926). Familial finger contracture and associated familial knee-joint subluxation. Fournal of the American Medical Association, 86, 395-396.

Nevin, N. C., Hurwitz, L. J., and Neill, D. W. (1966). Familial camptodactyly with taurinuria. Fournal of Medical Genetics, 3, 265-268.

Parish, J. G., Horn, D. B., and Thompson, M. (1963). Familial streblodactyly with amino-aciduria. British Medical fournal, 2, 1247-1250.

Penrose, L. S. (1969). Dermatoglyphics in trisomy 17 or 18. fournal of Mental Deficiency Research, 13, 44-59.

Schmidt, L. von (1921). Die Streckung krummer Finger. Deutsche medizinische Wochenschrift, 47, 845-848.

Spear, G. S. (1946). The inheritance of flexed fingers. Fournal of Heredity, 37, 189-192.

Tamplin, R. W. (1846). Lectures on the Nature and Treatment of Deformities. Barrington and Haswell, Philadelphia.

Welch, J. P. and Temtamy, S. A. (1966). Hereditary contractures of the fingers (camptodactyly). Fournal of Medical Genetics, 3, 104-113.

Whitman, R. (1930). A Treatise on Orthopedic Surgery, 9th ed. Lea and Febiger, Philadelphia. 